\title{
Sınıf Öğretmen Adaylarının Fen Laboratuvarında Argümantasyon Tabanlı Öğretime Yönelik Görüşlerinin İncelenmesi*
}

\author{
Gamze KARAER, Ersin KARADEMIR, Özden TEZEL**
}

Sınıf Öğretmen Adaylarının Fen Laboratuvarında Argümantasyon Tabanlı Öğretime Yönelik Görüşlerinin Incelenmesi

\section{Özet}

Bu çalışma kapsamında, Argümantasyon Tabanlı Öğretim (ATÖ) yönteminin fen bilimleri laboratuvar uygulamalarında kullanılabilen etkili bir öğretim yöntemi olduğu durumu sınıf öğretmen adaylarının görüşleri ve hazırbulunuşluk durumları incelenerek ortaya koyulmuştur. Nitel araştırma yöntemlerinden durum çalışması kullanılarak yürütülen bu çalışmada toplamda 28 sınıf öğretmen adayı ile sekiz haftalık ATÖ uygulaması yapılmıştır. Uygulamanın ilk ve son haftalarında öğretmen adaylarının görüşlerinde ve hazırbulunuşluk durumlarında meydana gelen değişimi belirlemek için veri toplama aracı olarak "Argümantasyon Tabanlı Öğretime Yönelik Görüş Formu (ATÖYG)" ve "Argümantasyon Tabanlı Öğretime Giriş Etkinliği Formu (ATÖGE)" kullanılmıştır. Ayrıca uygulamanın son haftasında öğretmen adaylarının derse katıımlarında artış gözlenmiş ve deneylerin teorik kısımlarında -gerekçe, veri, iddia, çürütücü, destekleyici, sınırlayıcı- gibi argüman öğelerini kullanarak bilimsel tartışma gerçekleştirebildikleri görülmüştür. Bu doğrultuda, ATÖ yönteminin fen laboratuvar uygulamalarını zenginleştirmek amacıyla daha sık kullanılmasının gerektiği düşünülmektedir.

Anahtar Kelimeler: Argümantasyon, Sınıf Öğretmen Adayları, Fen Laboratuvarı
Determination of Pre-service Classroom Teachers' Opinions Towards the Argumentation Based Instruction Method in Science Laboratory

\section{Abstract}

The aim of this study is to examine that the case of Argumantation Based Instruction (ABI) efficacy in the science laboratory courses according to pre-service classroom teachers' opinions and their readiness cases. This study was designed with case study and 28 pre-service classroom teachers participated. Data was collected via "Interview Form towards $A B I$ " and " $A B I$ Activity Form". Interviews and introduction activity were carried out two times before and after instruction. After instruction, there were eight pre-service classroom teachers done introduction activity completely using argumentation items. Throughout the process, pre-service teachers learned how the argumentation items could be used in the experiments. Depending on these results, science-teaching process apart from science laboratory activities can be enriched by ABI method.

Key Words: Argumentation, Pre-Service Classroom Teachers, Science Laboratory

\section{Giriş}

Fen bilimleri dersi öğretmen ve öğrenci iletişiminin kolay kurulabileceği bir iletişim

\footnotetext{
*Bu makale ESOGÜ BAP tarafından desteklenen 2016/21A104 nolu projeden üretilmiştir.

**aamze KARAER, Arş. Gör., Hakkari Üniversitesi, Özel Eğitim Bölümü, gmzkaraer26@gmail.com; ORCID ID: orcid.org/0000-0002-0389-3938, Ersin KARADEMIR, Doç. Dr., Eskişehir Osmangazi Üniversitesi, Matematik ve Fen Bilimleri Eğitimi Bölümü, eekarademir@gmail.com , ORCID ID: orcid.org/ 0000-0002-8519-622X, Özden TEZEL, Prof. Dr., Eskişehir Osmangazi Üniversitesi, Matematik ve Fen Bilimleri Eğitimi Bölümü, ozdentezel@gmail.com, ORCID ID: orcid.org/ 0000-0002-9930-7058
} 
ortamı yaratır. Çocuğun yaşantılarını kendine özgü atmosferi içerisinde değerlendiren, bilgi ve beceri düzeyini, yaşantısal deneyimler yoluyla etkin bir şekilde kullanılmasını sağlayan bir derstir (Gürdal, Şahin ve Çağlar, 2001). Öğrencilerin fen bilimlerine ilişkin becerileri elde edebilmeleri ve bu becerileri günlük hayatta kullanabilmeleri için okul içi ve okul dışı eğitim-öğretim ortamlarının onların zihinsel ve bilişsel gelişimlerini destekleyici şekilde düzenlenmesi büyük önem taşımaktadır. Bu doğrultuda hazırlanan Fen Bilimleri Dersi Öğretim Programları, öğrencilerin öğrenme sürecinde aktif olabilecekleri, karşılaştıkları problemlere çözüm üretebilen ve sorumluluk sahibi bireyler olabilmeleri için tasarlanmışlardır (Milli Eğitim Bakanlığı [MEB], 2006; 2013; 2017, 2018). 2013 yılında yapılan 4+4+4 düzenlemesi ile fen bilimleri dersi ilkokul üçüncü sınıf düzeyinden itibaren uygulanmaya başlanmıştır. Fen bilimleri dersi öğretim programına göre derslerde öğrencilerin etkin, öğretmenin ise rehber olduğu öğrenme ortamları problem, proje, argümantasyon, iş birliği, araştırma-sorgulamaya dayalı öğrenme yaklaşımları ile zenginleştirilebilmektedir (MEB, 2018). Öğrenme ortamlarının zenginleştirilmesi ve öğrencilerin fikirlerini rahatça ifade edebilmeleri adına geliştirilen teknikler arasında bulunan argümantasyon öğrencilerin öğrenme sürecine katılımlarını artırmakta ve bu sebeple daha etkin bir öğrenme ortamı oluşturulabilmektedir (Günel, Kıngır ve Geban, 2012). Ülkemizde 2004'te başlayan fen bilimleri dersleri ile ilgili müfredat reform hareketlerinde resmi eğitim programlarında "bütün bireylerin fen okuryazar olması" vizyonu temel alınmıştır (MEB, 2006; 2013; 2018 ). Bu vizyon doğrultusunda, bilimsel tartışmalarda öne sürülen iddiaları, gerekçeleri, muhakeme ve argümanları eleştirel olarak değerlendirebilecek ve bilimin düşünme yollarını kullanarak bilinçli kararlar verebilecek bilim okur yazarı bir toplum oluşturmak öncelikli hedefler haline gelmiştir (Tümay, Köseoğlu ve Budak, 2008). Son yıllarda yapılan çalışmalar öğrenciyi ezbere yönelten etkinlikler yerine öğrencinin düşünmesini ve öğrenme sürecine aktif katılımını sağlayan alternatif yaklaşımları ön plana çıkarmaktadır. Bu alternatif yaklaşımlardan biri olarak adını duyuran Argümantasyon Tabanlı Öğretim (ATÖ) yönteminin fen bilimleri öğretimindeki önemi giderek artmaktadır (Üstünkaya ve Savran Gencer, 2012). Argümantasyon, Toulmin'e (2003) göre bir iddia ve onun haklılığı olarak tanımlanırken; Driver, Newton ve Osborne'a (2000) göre grupça ya da bireysel olarak yapılan düşünme ve yazma etkinliğidir. Argümantasyon yönteminin öğretimde kullanılabilmesi için bilim insanları tarafından pek çok argümantasyon modeli ortaya atılmıştır (Giere, 1991; Kelly ve Takao, 2002; Lawson, 2003; Sandoval, 2003; Schwarz, Neuman, Gil ve llya, 2003; Zohar ve Nemet, 2002). Bu modellerin içinde en çok bilinen ve yaygın olarak kullanılan model, Stephen Toulmin'in 1958 yılında "The Uses of Argument" isimli kitabında ortaya attığı modeldir (Driver ve diğ., 2000; Erduran ve Jiménez-Aleixandre, 2008; Erduran, Simon ve Osborne, 2004; Simon, Erduran ve Osborne, 2006). Toulmin'in argümantasyon modelinde bulunan bileşenler; veri, iddia, gerekçe, destekleyici, sınırlayıcı ve çürütücüdür. Toulmin'in argümantasyon modelinde yer alan veri, iddia, gerekçe ve destekleyi- 
ci bileşenleri ana bileşen olarak kabul edilirken, sınırlayıcı ve çürütücü bileşenleri karmaşık argümanlarda kullanılan diğer iki bileşen olarak kabul edilmektedir (Driver ve diğ., 2000; Simon ve diğ., 2006). Toulmin'in argümantasyon modelindeki bileşenler aşağıdaki gibi tanımlanmaktadır;

Veri: İddiaları desteklemek için kullanılan ifadelerdir.

İdia: Sahip olunan fikirlerin öne sürümüdür.

Gerekçe: Veri ile iddia arasındaki ilişkiyi açıklamak için kullanılan ifadelerdir.

Destekleyiciler: Var olan iddayı desteklemek için kullanılan temel varsayımdır.

Sınırlandırıcılar: İddiaların sahip olduğu doğruluğun altındaki özel koşullardır.

Çürütme: Bir iddianın ya sınırlandırıcısı ile ya da veri, gerekçe, destekleyici gibi bileşenler ile çatışan ifadelerdir (Koçak, 2013, s.15). Toulmin'in argümantasyon modeli Şekil 1 'de görülmektedir.

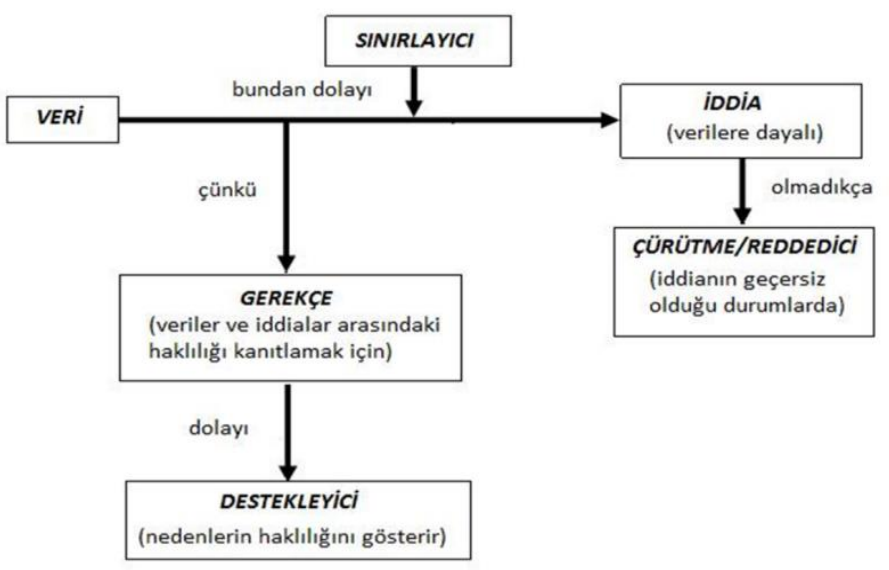

Şekil 1. Toulmin'in argümantasyon modeli (Koçak, 2013, s.15)

Fen bilimleri derslerinde öğrencilerin sunumlarının, küçük grup tartışmalarının ve argümantasyon becerilerinin gelişmesini destekleyen uygun argümantasyon stratejileri bulunmaktadır (Osborne, Erduran ve Simon, 2004). Fen bilimleri öğretiminde kullanılan argümantasyon stratejileri; ifadeler tablosu, karikatürlerle yarışan teoriler, öğrenci fikirleri kavram haritası, öğrenciler tarafından yapılan bir fen deneyi raporu, hikâyelerle yarışan teoriler, kanıt ve fikirlerle yarışan teoriler, bir argüman oluşturma, tahmin et- gözle- açıkla ve bir deney tasarlama olarak belirtilmektedir (Osborne ve diğ., 2004). ATÖ yöntemi içeri- 
sinde yer alan tekniklerin etkililiğini araştıran çalışmalar incelendiğinde; bu çalışmalarda araştırmanın yapı iskelesini oluşturan yöntem kısmında farklılıklar olduğu görülmektedir. Alanyazın taraması sonucunda bu çalışmaların genellikle; deneysel çalışmalar, durum çalışmaları ve kuramsal çalışmalar oldukları görülmektedir (Akpınar, Ardaç ve Er-Amuce, 2014; Balcı ve Yenice 2016; Hiğde ve Aktamış, 2017; Kaptan ve Aydın, 2014; Lawson, 2003; Öğreten ve Uluçınar Sağır, 2014; Sandoval, 2003; Suzuki, 2015; Şahin ve Hacıoğlu, 2010; Yan ve Erduran, 2008; Zohar ve Nemet, 2002). Incelenen çalışmalarda çalışma grubu olarak fen bilgisi öğretmenleri, fen bilgisi öğretmen adayları ve ilköğretim öğrencileri belirlenmiştir (Aktamış ve Atmaca, 2016; Aktamış ve Hiğde, 2015; Berland ve Mcneil, 2010; Hiğde ve Aktamış, 2017; Kabataş Memiş, 2014; Mcneil, 2011; Öğreten ve Uluçınar Sağır, 2014; Yeşildağ Hasançebi ve Günel, 2013). Ancak fen bilimleri derslerinin ilkokul üçüncü sınıftan itibaren uygulanmaya başlanması, fen bilimleri öğretiminde kullanılan alternatif öğretim yaklaşımlarının sınıf öğretmenleri ve sınıf öğretmen adayları açısından da bilinmesini gerekli kılmaktadır. ATÖ yönteminin sınıf öğretmen adayları açısından da fen bilimleri öğretiminde kullanılan etkili bir öğretim yöntemi olduğu durumunun belirlenmesi, gelecekte sınıf öğretmenleri ya da sınıf öğretmen adayları ile bu konuda yapılacak çalışmalara temel oluşturması ya da yol göstermesi açısından önem oluşturmaktadır. Bu doğrultuda, alanyazında yer alan deneysel araştırmalara alternatif olarak nitel araştırma yöntemlerinden durum çalışması kullanılarak ATÖ yönteminin fen laboratuvar uygulamalarındaki etkililiği sınıf öğretmen adaylarının görüşlerinde ve hazırbulunuşluk durumlarında meydana gelen değişikliğe göre ortaya koyulabilir. Çünkü farklı durumlarda etkililiği araştırılmış bir kuram ya da öğretim yöntemi varsa durum çalışmalarından bütüncül tek durum deseni ile bu durumun teyit edilmesi ya da çürütülmesi yapılmaktadır (Yıldırım ve Şimsek, 2015). Bu çalışma kapsamında; sınıf öğremen adaylarının fen bilimleri laboratuvar uygulamalarında argümantasyon yönteminin kullanılmasına ilişkin görüşleri ve hazırbulunuşluk durumlarının belirlenmesi ile ATÖ yönteminin fen bilimleri laboratuvar uygulamalarında kullanılabilen etkili bir öğretim yöntemi olduğu durumu incelenecektir. Belirtilen gerekçe doğrultusunda bu çalışmanın amacı, fen bilimleri laboratuvar uygulamaları dersinde sekiz hafta boyunca yapılan uygulamanın ilk ve son haftalarında sınıf öğretmen adaylarının görüşleri ve hazırbulunuşluk durumları arasında meydana gelen değişimler incelenerek ATÖ yönteminin fen bilimleri laboratuvar uygulamalarında kullanılabilen bir öğretim yöntemi olduğu durumunu ortaya koymaktır. Bu amaç doğrultusunda aşağıda belirtilen araştırma sorularına yanıt aranmaya çalışılmıştır.

Fen Bilimleri Laboratuvar Uygulamaları dersi kapsamında yapılan argümantasyon uyulamasının ilk ve son haftasında sınıf öğretmen adaylarının ATÖ yöntemine yönelik görüşleri arasında nasıl değişim görülmektedir? 
$>$ Fen Bilimleri Laboratuvar Uygulamaları dersi kapsamında yapılan argümantasyon uygulamalarının ilk haftasında ve son haftasında sınıf öğretmen adaylarının ATÖ yöntemine yönelik belirlenen hazırbulunuşluk durumları arasında nasıl bir değişim görülmektedir?

\section{Yöntem}

ATÖ yönteminin fen bilimleri laboratuvar uygulamalarında kullanılabilen etkili bir öğretim yöntemi olduğu durumunu ortaya koymak amacıyla nitel araştırma yöntemlerinden durum çalışması kullanılmıştır. ATÖ yönteminin fen bilimleri derslerinde kullanılan etkili bir öğretim yöntemi olduğu fen bilimleri öğretmenleri, fen bilimleri öğretmen adayları, ilkokul ve ortaokul öğrencileri üzerinde yapılan deneysel çalışmalarla doğrulanmıştır. Bu çalışmada ATÖ yönteminin fen bilimleri laboratuvar uygulamalarında kullanılabilen etkili bir öğretim yöntemi olduğu durumu sınıf öğretmen adaylarının uygulamanın ilk ve son haftalarında görüşlerinde ve hazırbulunuşluk durumlarında meydana gelen değişimler incelenerek ortaya koyulmuştur. Belirtilen durum, durum çalışması desenlerinden "bütüncül tek durum deseni" kullanılarak ortaya koyulmuştur. Bütüncül tek durum deseni, tek bir analiz birimi (bir birey, bir kurum, bir program, bir yöntem) olduğu durumlarda üç şekilde kullanılmaktadır. İlk olarak eğer ortamda iyi formüle edilmiş bir kuram ya da yöntem varsa bunun teyit edilmesinde ya da çürütülmesinde kullanılabilir. İkinci olarak genel standartlara uymayan aşırı, aykırı veya kendine özgü durumların çalışılmasında bütüncül tek durum deseni kullanılabilir. Son olarak, daha önce hiç kimsenin çalışmadığı veya ulaşamadığı durumlarda bütüncül tek durum deseni kullanılabilir. Böyle durumların çalışılması, daha sonraki araştırmacılar için daha önce bilinmeyen belirli bir konunun su yüzüne çıkması ve daha sonra yapılacak araştırmalara temel oluşturması ya da yol göstermesi açısından önemlidir (Yıldırım ve Şimşek, 2015). Bu çalışma kapsamında, ATÖ yönteminin fen bilimleri laboratuvar uygulamalarında kullanılabilen etkili bir öğretim yöntemi olduğu durumu sınıf öğretmen adaylarının görüşleri ve hazırbulunuşluk durumları doğrultusunda incelenmesi, bütüncül tek durum deseninin farklı ortamlarda etkililiği araştırılmış bir öğretim yönteminin fen bilimleri laboratuvar uygulamalarında sınıf öğretmen adayları açısından da teyit edilmesini sağlayacaktır. ATÖ yönteminin fen bilimleri laboratuvar uygulamalarında sınıf öğretmen adaylarının görüşleri ve hazırbulunuşluk durumları açısından etkililiği araştırılacağı için analiz birimi olarak "sınıf öğretmen adayları" belirlenmiştir. Bu doğrultuda, sınıf öğretmen adaylarının uygulamanın ilk ve son haftalarında görüşlerini ve hazırbulunuşluk durumlarını belirlemek amacıyla veri toplama aracı olarak Argümantasyon Tabanlı Öğretime Yönelik Görüş (ATÖYG) formu ve Argümantasyon Tabanlı Öğretime Giriş Etkinliği (ATÖGE) formu kullanılmıştır. Görüşme formunda bulunan sorular ise, araştırmacılar tarafından hazırlanmıştır. ATÖYG ve ATÖGE formları öğrencilere uygulamanın ilk ve son haftasında olmak üzere iki kez uygulanmıştır. 


\subsection{Katılımcılar}

Araştırmanın çalışma grubunu, 2015-2016 öğretim yılında Eskişehir Osmangazi Üniversitesi, Eğitim Fakültesi, Temel Eğitim Bölümü Sınıf Öğretmenliği programında öğrenim gören 28 öğretmen adayı (27 kadın, 1 erkek) oluşturmaktadır. Çalışma grubunun belirlenmesinde olasılıksız örnekleme yöntemlerinden kolay ulaşılabilir durum örneklemesi yöntemi kullanılmıştır. Bu örnekleme yöntemi araştırmacıya hız ve pratiklik kazandırır. Çünkü bu yöntemde araştırmacı, yakın olan ve erişilmesi kolay olan durumu seçer (Yıldırım ve Şimşek, 2015). Çalışmada bahar döneminde alınan Fen Bilimleri Laboratuvar Uygulamaları II dersi kapsamında öğretmen adaylarına ATÖ etkinlikleri yaptırılmıştır.

\subsection{Veri Toplama Araçları}

süresince yapılan öğretim uygulamaları video kayıtları yardımı ile kayıt altına alınmıştır. Araştırmada veri toplama aracı olarak "Argümantasyon Tabanlı Öğretime Yönelik Görüş (ATÖYG) Formu" ve "Argümantasyon Tabanlı Öğretime Giriş Etkinliği (ATÖGE) Formu" kullanılmıştır. ATÖYG ve ATÖGE formları araştırmacılar tarafından uzman görüşleri alınarak hazırlanmıştır. Araştırma süresince yapılan öğretim uygulamaları video kayıtları yardımı ile kayıt altına alınmıştır.

\subsubsection{ATÖYG Formu}

Argümantasyon Tabanlı Öğretime Yönelik Görüş (ATÖYG) Formu; sınıf öğretmen adaylarına Fen Bilimleri Laboratuvar Uygulamaları II dersi kapsamında uygulamanın ilk ve son haftasında uygulanarak ATÖ’ye yönelik görüşlerinin ne ölçüde değiştiğini belirlemek amacıyla kullanılmıştır. Görüşme formu açık uçlu sorulardan oluşmaktadır. Rubin'e (1983) göre; görüşmeler sabit format anket görüşmesi, açık uçlu anket görüşmesi, açık uçlu duyarlaştırıcı görüşme ve açık uçlu yoğunlaştırılmış görüşme olarak dört şekilde yapılmaktadır. Açık uçlu anket görüşmesinde bir dizi standart soru seti bulunmaktadır ve görüşülen birey bu sorulara istediği biçimde ve öznel olarak yanıt vermekte serbesttir (Akt: Gürdoğan Bayır, Göz ve Bozkurt, 2014). Bu çalışma kapsamında açık uçlu sorulardan oluşan form öğretmen adaylarına uygulamanın ilk ve son haftasında fen bilimleri laboratuvar uygulamaları dersinin ilk saatinde dağıtılmış ve yaklaşık 45 dakika süre verilerek öğretmen adaylarından formu doldurmaları istenmiştir. ATÖYG formunun düzenlenmesinde fen bilimleri eğitiminde uzman iki öğretim üyesinin ve iki sınıf öğretmeninin uzman görüşleri alınmıştır. Uzman görüşleri dikkate alınarak sorulara son şekilleri verilmiştir. ATÖYG formu sınıf öğretmen adaylarının ATÖ yöntemine yönelik görüşlerini belirlemek amacıyla beş adet açık uçlu sorudan oluşmaktadır (Ek-1). 


\subsubsection{ATÖGE Formu}

Argümantasyon Tabanlı Öğretime Giriş Etkinliği (ATÖGE) Formu; sınıf öğretmen adaylarına uygulamanın ilk haftasında ve son haftasında uygulanarak ATÖ yöntemine yönelik hazırbulunuşluklarında meydana gelen değişimi belirlemek amacıyla kullanılmıştır (Karaer, 2016). ATÖGE formu iki bölümden oluşmaktadır. Birinci bölümde başlarında 1'den 6'ya kadar numaralar olan karışık argümantasyon ifadeleri yer alırken, ikinci bölümde veri, iddia, sınırlayıcı, gerekçe, destekleyici ve çürütücü gibi argüman öğelerinin doldurulacağı içi boş kutucuklardan oluşan bir argümantasyon modeli yer almaktadır. ATÖGE formunun birinci bölümünde yer alan ifadelerin oluşturulmasında McNeil ve Krajcik'den (2012) yararlanılırken; ikinci bölümde yer alan içi boş argümantasyon modeli için Toulmin'den (2003) yararlanılmıştır. Öğretmen adaylarının ifadeleri okuyarak hangi ifadenin iddia, veri, gerekçe, sınırlayıcı, destekleyici ya da çürütücü olduğunu bularak ifadelerin başlarında yer alan rakamları argümantasyon modeli üzerindeki içi boş kutucuklara yerleştirmeleri istenmiştir (Ek-2).

\subsection{Verilerin Toplanma Süreci}

Sınıf Öğretmenliği Lisans Programı Fen Bilimleri Laboratuvar Uygulamaları II (FBLU) dersi kapsamında yapılan uygulama ATÖ yöntemi kullanılarak toplamda sekiz hafta sürmüştür. FBLU Dersi kapsamında yapılan dokuz adet deney ATÖ stratejileri kullanılarak yürütülmüştür. Her hafta iki ders saati boyunca argümantasyon etkinlikleri ile planlanan fen deneyleri yapılmıştır. Uygulamanın ilk haftasında (birinci hafta) öncelikle ATÖYG formu kullanılarak öğretmen adaylarının argümantasyon yöntemi hakkında ne bildikleri ve ne düşündükleri öğrenilmiştir. İkinci olarak ATÖGE formu kullanılarak giriş I etkinliği yapılmıştır. Giriş I etkinliği kapsamında öğretmen adayları ATÖGE formunu doldurmuşlardır. $\mathrm{Bu}$ form ile uygulamaya başlamadan önce ATÖ yöntemine yönelik hazırbulunuşluk durumları belirlenmiştir. Üçüncü olarak ATÖ yöntemi hakkında tanıtım sunusu yapılmıştır. Belirtilen tanıtım sunusu; ATÖ yönteminin ne olduğu, nasıl ortaya çıktığı, nasıl uygulandığı ve stratejilerinin neler olduğu ile ilgili bilgiler içermektedir. ATÖ yönteminin ne olduğu başığı altında farklı bilim insanlarının ATÖ yöntemi hakkında yaptıkları tanımlar verilerek nasıl ortaya çıktığı açıklanmıştır. ATÖ yönteminin nasıl uygulandığı ve stratejilerinin neler olduğu başlığı altında Toulmin'in argümantasyon modeli tanıtılmıştır. Bu model şekilsel olarak gösterilerek hangi argümantasyon ögelerini içerdiği ve ögeler arasındaki ilişki açıklanmıştır. Bilimsel çalışmalardan alınan örnek argümantasyon ifadeleri kullanılarak bu ifadelerin hangi argümantasyon ögelerini içerdikleri ve bu argümantasyon ögelerini nasıl birbirinden ayırt edilebileceği açıklanmıştır. Ek olarak sınıflarda ATÖ yönteminin uygulanabilmesi için kullanılan argümantasyon stratejileri tanıtılmıştır. Son olarak, öğretmen adayları altışar kişilik gruplara ayrılmış ve her grup kendi grup temsilcisini belirlemiştir. Öğretmen adayları sınıf içi performansları dikkate alınarak gruplara ayrılmıştır. Gruplara 
ayrılmalarındaki amaç yapılacak etkinliklerin grup etkinlikleri olmasıdır. Etkinliklerde yer alan ifadelerin oluşturulmasında tartışma ve bilgi paylaşımının yapılması gerektidiği için öğretmen adayları gruplara ayrılmıştır. Uygulamanın ikinci haftasında "Maddeleri Ayırma Yöntemleri: Karikatürlerle Yarışan Teoriler" etkinliği ile argümantasyona giriş II etkinliği yapılmıştır. Bu etkinlik kapsamında "kâğıt kromatografi ile ayırma", "mıknatısın büyüsü" ve "buharlaştırma ile ayırma" deneyleri yapılmıştır. Öğretmen adayları deneyleri yapmaya başlamadan önce karikatürlerle yarışan teoriler argümantasyon stratejisi kullanılarak adaylara bu üç deney ile ilgili hazırlanmış bir karikatür dağıtılmış ve karikatür üzerinde yer alan ifadelerin hangisinin doğru olduğu gruplar arasında tartışılmıştır. Öğretmen adayları gruplar halinde bu ifadeler ile ilgili iddialarını ve gerekçelerini öne sürmüş ardından iddialarını desteklemek ya da çürütmek için deneyleri yapma aşamasına geçmişlerdir. Gruplar deneylerini yaptıktan sonra, etkinlik formunda yer alan iddia, kanıt ve gerekçe kısımlarını deney sonuçlarına göre doldurmuşlardır. Uygulamanın birinci ve ikinci haftasında yapılan giriş I ve II etkinlikleri öğretmen adaylarını argümantasyon sürecine hazırlamak amacıyla tasarlanmıştır. Uygulamanın üçüncü haftasında, "Atık Suların Arıtımı: Hikâyelerle Yarışan Teoriler" etkinliği yapılmıştır. Etkinlik kapsamında "su arıtım basamakları" deneyi yapılmıştır. Öğretmen adayları deney yapımına geçmeden önce hikâyelerle yarışan teoriler argümantasyon stratejisi içinde yer alan örnek hikâye üzerinden iddialarını belirlemişlerdir. İddialar belirlendikten sonra gruplar kendi iddialarının doğruluğunu diğer gruplara kanıtlamaya çalışmışlardır. Bu süreçte uygulamacılar yapılan iddialarının doğruluğu ya da yanlışlığı ile ilgili ipucu vermemiştir. Bu iddiaların doğruluğunu ispatlamak ya da çürütmek amacıyla deney yapımına geçmeleri ve deney sonuçlarına göre doğru yargıya varmaları istenmiştir. Uygulamanın dördüncü haftasında "Sabun Üretimi: Ifadeler Tablosu" etkinliği yapılmıştır. Deney yapımına geçmeden önce öğretmen adaylarına ifadeler tablosu etkinlik formu dağıtılmış ve bu form üzerinde yer alan soruların doğru ya da yanlış olarak tartışmaları istenerek kendi argümanlarını oluşturmaları istenmiştir. Daha sonra deney aşamasına geçerek deney sonucunda elde edilen veriler ile ifadeler tablosuna doldurulan argümanların desteklenmesi ya da çürütülmesi sağlanmıştır. Uygulamanın beşinci haftasında, "Tepkimeler I: İfadeler Tablosu" etkinliği ile "yangın söndürücü" deneyi yapılmıştır. Uygulamanın altıncı haftasında "Tepkimeler II: Argüman Oluşturma" etkinliği ile "volkan deneyi" ve "Tepkimeler III: Tahmin et-Gözle-Açıkla" etkinliği ile "mayalanma" deneyi yapılmıştır. Uygulamanın yedinci haftasında; "Asit mi Baz mı: Tahmin et-Gözle-Açıkla” etkinliği ile "lahana suyunun $\mathrm{pH}$ indikatörü olarak kullanılması" deneyi yapılmıştır. Uygulamanın son haftasında (sekizinci hafta) öğretmen adaylarından argümantasyon etkinlik raporları teslim alınmış ve adayların argümantasyona yönelik görüşlerinde meydana gelen değişimi incelemek için ilk hafta uygulanan ATÖYG formu tekrar uygulanmıştır. Son olarak, öğretmen adaylarının ATÖ’ye yönelik hazırbulunuşluklarında meydana gelen değişimi belirlemek amacıyla ATÖGE formu tekrar uygulanmıştır. 


\subsection{Verilerin Analizi ve Yorumlanması}

Araştırmada nitel veriler içerik analizi yöntemine göre analiz edilmiştir. İçerik analizinde temel amaç, toplanan verileri açıklayabilecek kavramlara ve ilişkilere ulaşmaktır. Betimsel analizde özetlenen ve yorumlanan veriler, içerik analizinde daha derin bir işleme tabi tutulmaktadır. Betimsel bir yaklaşımla farkedilemeyen kavram ve temalar bu analiz sonucu keşfedilmektedir (Yıldırım ve Şimşek, 2015). Araştırmada toplanan veriler önce transkript edilmiştir. Transkript edilirken önce soru yazıımıştır. Ardından o sorunun altına bütün öğretmen adaylarının verdiği cevaplar yazılmıştır. Birbirine benzeyen veriler belirli kavramlar ve temalar çerçevesinde bir araya getirilmiştir. Bu doğrultuda önce sorularla ulaşılmak istenen temalar belirlenmiştir. Daha sonra belirlenen temalarla ilişkili olan öğretmen adaylarının görüşlerinin yoğunlaştığı alt temalar belirlenmiştir. Her bir alt temayı açıklayan benzer öğretmen görüşleri ile de kodlar oluşturulmuş ve karşılarına frekans değerleri yazılmıştır. Belirlenen tema, alt tema ve kodlar okuyucunun anlayabileceği bir biçimde tablolalar halinde düzenleyerek yorumlanmıştır. Araştırmanın güvenirliğini sağlamak amacıyla araştırmanın verileri iki araştırmacı tarafından ayrı ayrı analiz edilmiştir. Yapılan bu analizler sonucunda temalar, alt temalar ve kodlar karşılaştırılmış, görüş ayrılığına düşülen noktalar belirlenmiş, bunun üzerine gerekli tartışmalar yapılarak temalara, alt temalara ve kodlara son şekli verilmiştir.

\section{Bulgular}

ATÖ yönteminin uygulandığı fen bilimleri laboratuvar uygulamaları dersinde sınıf öğretmen adaylarının uygulamanın başından sonuna görüşleri ve hazırbulunuşluk durumlarında meydana gelen değişimlerin inceleme konusu yapıldığı araştırma bulguları alt başııklar biçiminde sırası ile verilmiştir.

\subsection{Sınıf Öğretmen Adaylarının ATÖ Yöntemine Yönelik Görüşleri}

Uygulamanın ilk ve son haftalarında öğretmen adaylarının “Argümantasyon Tabanlı Öğretime Yönelik Görüş (ATÖYG)” formunda yer alan beş adet açık uçlu soruya verdikleri yanıtlar doğrultusunda, ATÖ yönteminin tanımı, avantajları/dezavantajları ve fen bilimleri laboratuvarında kullanımı şeklinde üç adet ana tema oluşturulmuştur. Belirlenen ana temalar ve alt temalar Şekil 2'de verilmiştir. 


\section{Gamze KARAER | Ersin KARADEMIR | Özden TEZEL}

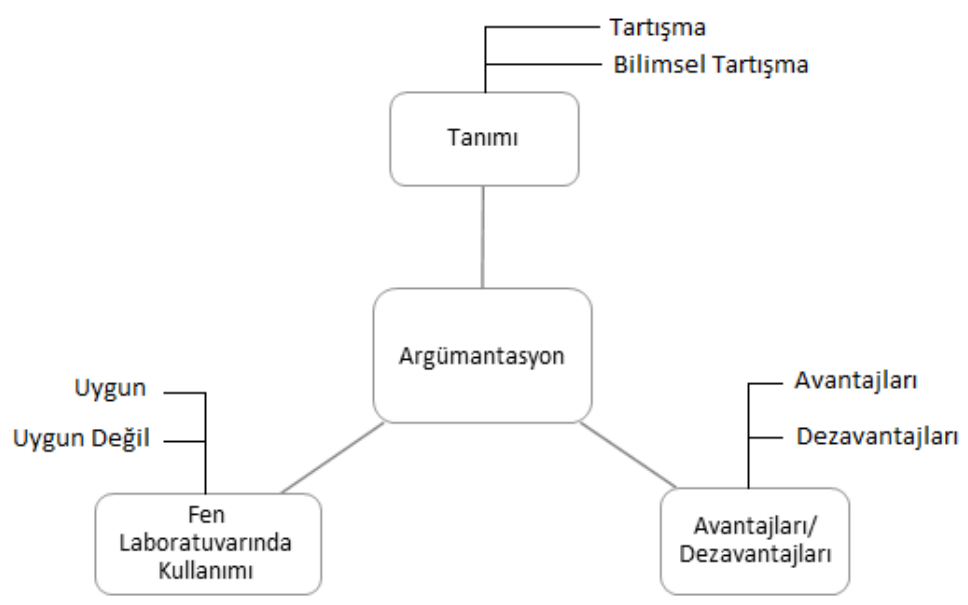

Şekil 2. Uygulamanın ilk ve son haftalarında ATÖYG formundan elde edilen temalar ve alt temalar

\subsubsection{ATÖ Yönteminin Tanımına Iliş̧kin Bulgular}

Argümantasyon tabanlı öğretim yönteminin tanımı temasına ilişkin uygulamanın ilk ve son haftalarında ATÖYG formuna verilen yanıtlardan elde edilen alt temalar ve kodlamalar Tablo 1'de sunulmuştur. 
Eskişehir Osmangazi Üniversitesi Sosyal Bilimler Dergisi

Tablo 1. Argümantasyon Tabanlı Öğretim Yönteminin Tanımı

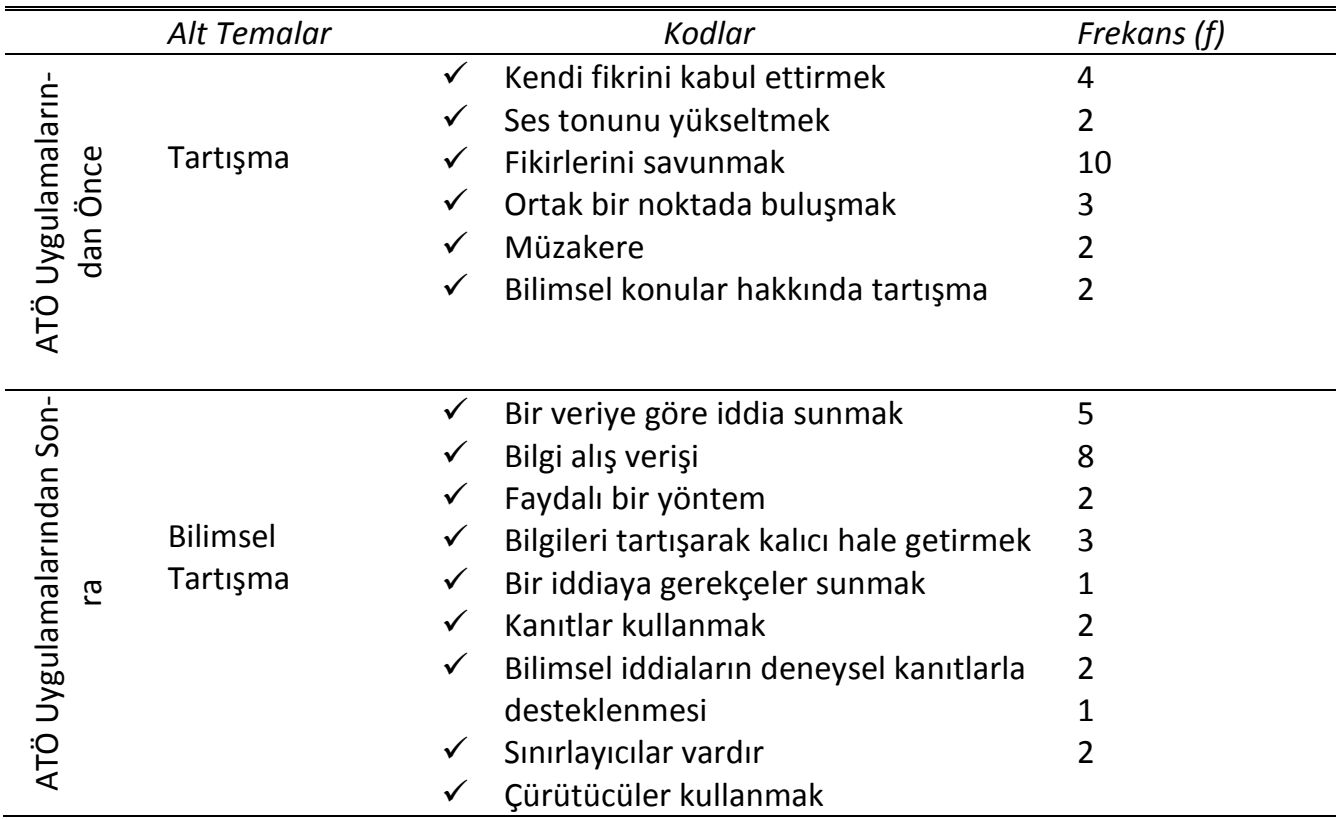

Tablo 2'ye göre, ATÖ uygulamasının ilk ve son haftalarında sınıf öğretmen adaylarının ATÖ yönteminin tanımı temasına ilişkin görüşlerinde farklııklar meydana geldiği görülmektedir. ATÖ yöntemine dayalı fen bilimleri laboratuvar uygulamalarının ilk haftasında öğretmen adaylarının verdikleri yanıtlar doğrultusunda ATÖ yöntemi tartışma olarak tanımlanmıştır. Öğretmen adaylarından bazıları tartışma alt temasıyla ilişkili olarak ATÖ yöntemini; kendi fikrini kabul ettirme $(f=4)$, ses tonunu yükseltme ( $f=2)$, fikirlerini savunmak $(f=10)$, ortak bir noktada buluşmak $(f=3)$, müzakere $(f=2)$ ve bilimsel konular hakkında tartışma $(f=2)$ olarak belirtmişlerdir. Öğretmen adaylarının bir kısmı $(f=5)$ ise ATÖ yönteminin tanımı teması kapsamında görüş belirtmemiştir. Uygulamanın ilk haftasında bazı öğretmen adaylarının bu temaya ilişkin doğrudan ifade örnekleri şu şekildedir:

Öğretmen adayı 4: "Karşıt görüşler vardır. Herkes kendi fikrini kabul ettirmeye çalışır. Karşıt görüşlerin olması tartışmalara neden olur ve ses tonu yükselir."

Öğretmen adayı 26: "Bir fikir ortaya atılır. Herkes onun üzerinden kendi fikrini savunur."

Uygulamanın son haftasında elde edilen verilere göre öğretmen adaylarının görüşleri doğrultusunda bilimsel tartışma alt temasının oluştuğu görülmüştür. Bu doğrultuda ATÖ yöntemini; bir veriye göre iddia sunmak $(f=5)$, bilgi alış verişi $(f=8)$, faydalı bir yöntem 


\section{Gamze KARAER | Ersin KARADEMiR | Özden TEZEL}

$(f=2)$, bilgileri tartışarak kalıcı hale getirmek $(f=3)$, bir iddiaya gerekçeler sunmak $(f=1)$, kanıtlar kullanmak ( $f=2)$, bilimsel iddiaların deneysel kanıtlarla desteklenmesi $(f=2)$, sınırlayıcılar vardır ( $\mathrm{f}=1$ ) ve çürütücüler kullanmak ( $\mathrm{f}=2$ ) olarak tanımlamışlardır.

Öğretmen adayı 1: "Bir iddia ortaya atılır. Iddianın doğruluğu gerekçe, çürütücüler ve destekleyiciler kullanılarak tartışılır."

Öğretmen adayı 4: "Tartışmanın daha bilimsel ve kurallı şekilde ve teorik bilgilere dayandırılarak yapılması olduğunu düşünüyorum."

\subsubsection{ATÖ Yönteminin Avantajları/ Dezavantajları Temasına İlişkin Bulgular}

ATÖ yönteminin avantajları ve dezavantajları temasına ilişkin sınıf öğretmen adaylarının uygulamanın ilk ve son haftalarında ATÖYG formuna verilen yanıtlardan elde edilen alt temalar ve kodlamalar Tablo 2'de sunulmuştur. 
Tablo 2. Argümantasyon Tabanlı Öğretim Yönteminin Avantajları ve Dezavantajları

\begin{tabular}{|c|c|c|c|}
\hline & Alt Temalar & Kodlar & Frekans (f) \\
\hline \multirow{14}{*}{ 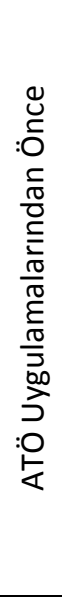 } & \multirow{7}{*}{ Avantajları } & $\checkmark$ Etkin katılım & 6 \\
\hline & & $\checkmark$ Kendini ifade edebilme & 1 \\
\hline & & $\checkmark$ Özgür düşünme & 9 \\
\hline & & $\checkmark$ Fikir paylaşımı & 1 \\
\hline & & $\checkmark$ Farklı bakış açısı kazanmak & 3 \\
\hline & & $\checkmark$ Kalıcılık & 1 \\
\hline & & $\checkmark$ Öğrenci ilgisi artar & 3 \\
\hline & \multirow[t]{7}{*}{ Dezavantajları } & $\checkmark$ Fikir ayrılıkları & 1 \\
\hline & & $\checkmark$ Muhalif tavırlar & 1 \\
\hline & & $\checkmark$ Zaman kaybı & 3 \\
\hline & & $\checkmark$ Deneyler yapılamaz & 2 \\
\hline & & $\checkmark$ Kafa karışıklığı yaratır & 1 \\
\hline & & $\checkmark$ Yeterli bilgiye sahip olmayan öğrenciler pasif kalır & 3 \\
\hline & & $\checkmark$ Çıkmaza sürükler & 1 \\
\hline \multirow{13}{*}{ 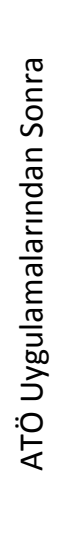 } & \multirow{8}{*}{ Avantajları } & $\checkmark$ Bilgilerin kalıcılığını sağlar & 9 \\
\hline & & $\checkmark$ Aktif öğrenme & 8 \\
\hline & & $\checkmark$ Bilgileri sorgulama & 4 \\
\hline & & $\checkmark$ Merak duygusunun uyanması & 1 \\
\hline & & $\checkmark$ Eğlenceli öğrenme & 2 \\
\hline & & $\checkmark$ Fikirlerin doğruluğunu kanıtlama & 5 \\
\hline & & $\checkmark$ Öğrenci merkezli bir yöntem & 1 \\
\hline & & $\checkmark$ Günlük hayata aktarma & 1 \\
\hline & \multirow[t]{5}{*}{ Dezavantajları } & $\checkmark$ Tartışma esnasında yanlış bilgiler kodlanabilir & 3 \\
\hline & & $\checkmark$ Zaman alıcı bir yöntem & 9 \\
\hline & & $\checkmark$ Ders saati yetersiz & 1 \\
\hline & & $\checkmark$ Kafa karışıklığı yaratır & 3 \\
\hline & & $\checkmark$ Dezavantajı yok & 7 \\
\hline
\end{tabular}

Tablo 2'ye göre, sınıf öğretmen adayları uygulamanın ilk ve son haftalarında ATÖ yönteminin faydalarından ve sınırlılıklarından bahsetmişlerdir. Tablo 2'ye göre uygulamanın ilk haftasında ATÖ yönteminin avantajları konusunda etkin katılım ( $f=6)$, kendini ifade edebilme $(f=1)$, özgür düşünme $(f=9)$, fikir paylaşımı $(f=1)$, farklı bakış açısı kazanmak $(f=3)$, kalıcılık ( $f=1$ ) ve öğrenci ilgisi artar $(f=3)$ gibi konularda avantajlarının olduğu belirtilmiştir. Bazı öğretmen adayları uygulamalardan önce ATÖ yönteminin avantajları ve dezavantajları konusunda bir görüş belirtmemiştir $(f=5)$. Uygulamanın son haftasında öğretmen adayları bilgilerin kalıcılığını sağlar $(f=9)$, aktif öğrenme $(f=8)$, bilgileri sorgulama $(f=4)$, merak duygusunun uyanması $(f=1)$, eğlenceli öğrenme $(f=2)$, fikirlerin doğruluğunu kanıtlama $(f=4)$, öğrenci merkezli bir yöntem $(f=1)$ ve günlük hayata aktarma $(f=1)$ gibi 
konularda ATÖ yönteminin avantajlarının olduğunu belirtmişlerdir. Uygulamanın ilk haftasında öğretmen adayları ATÖ yönteminin fikir ayrılıkları $(f=1)$, muhalif tavırlar $(f=1)$, zaman kaybı $(f=3)$, deneylerin yapılamaması $(f=2)$, kafa karışıklığı yaratması $(f=1)$, yeterli bilgiye sahip olmayan öğrencilerin pasif kalması $(f=3)$ ve çıkmaza sürüklemesi $(f=1)$ gibi durumlara neden olduğu için dezavantajlı bir yöntem olabileceğini belirtmişlerdir. Uygulamanın son haftasında öğretmen adayları tartışma esnasında yanlış bilgiler kodlanabilmesi $(f=3)$, zaman alıcı bir yöntem olması $(f=9)$, ders saatinin yetmemesi $(f=1)$ ve kafa karışıklığı yaratması $(\mathrm{f}=3$ ) gibi konularda dezavantajlarının olduğunu belirtmişlerdir. Uygulamanın son haftasında bazı öğretmen adayları bir görüş belirtmezken $(f=3)$, bazı öğretmen adayları ATÖ yönteminin herhangi bir dezavantajının olmadığını belirtmiştir ( $f=7)$. Uygulamanın ilk ve son haftalarında öğretmen adaylarının görüşlerine göre ATÖ yönteminin etkin katılım ve bilgilerin kalıcılığını sağlaması konularında ortak görüşlerin olduğu belirlenmiştir. Uygulamanın ilk haftasında ATÖ yönteminin zaman kaybına neden olacağı$\mathrm{nı}(\mathrm{f}=3)$ belirten öğretmen adayı görüşleri uygulamanın son haftasında artış göstermiştir $(f=9)$. Uygulamanın ilk ve son haftalarında ATÖ yönteminin kafa karışıklığı yaratacağı yönünde ortak bir görüşün olduğu belirlenmiştir. Uygulamanın son haftasında bu görüşe sahip öğretmen adayı sayısında artış olduğu belirlenmiştir. Uygulamanın ilk ve son haftalarında bazı öğretmen adaylarının bu temaya ilişkin görüşlerinde meydana gelen değişimleri ortaya koyan doğrudan ifade örnekleri şu şekildedir:

Uygulamanın ilk haftası görüş

Öğretmen adayı 25: "Avantajlı bir yöntem olduğunu düşünmüyorum. Ders esnasında zaman kaybına yol açabilir."

Uygulamanın son haftası görüş

Öğretmen adayı 25: "Teorik bilgileri düz anlatımla değil de aktif şekilde konuşmuş olduk. Ancak zaman en büyük sorun. Argümantasyon yapılacak diye deneyler aksadı."

\subsubsection{ATÖ Yönteminin Fen Laboratuvarında Kullanımı Temasına İlişkin Bulgular}

Argümantasyon tabanlı öğretim yönteminin fen laboratuvarında kullanımı temasına ilişkin uygulamanın ilk ve son haftalarında ATÖYG formuna verilen yanıtlardan elde edilen alt temalar ve kodlamalar Tablo 3'te sunulmuştur. 
Tablo 3. Argümantasyon Tabanlı Öğretim Yönteminin Fen Laboratuvarında Kullanımı

\begin{tabular}{|c|c|c|c|c|}
\hline & Alt Temalar & Ko & & Frekans (f) \\
\hline \multirow{8}{*}{ 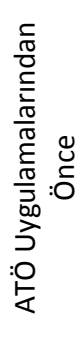 } & \multirow{5}{*}{ Uygun } & & Çocukların ilgisini çeker & 1 \\
\hline & & $\checkmark$ & Etkin ders işlenir & 4 \\
\hline & & $\checkmark$ & Yaparak-yaşayarak öğrenme & 1 \\
\hline & & $\checkmark$ & Bilimsel tartışma becerisi & 1 \\
\hline & & $\checkmark$ & Kalıcı öğrenme & 3 \\
\hline & \multirow[b]{2}{*}{ Uygun Değil } & $\checkmark$ & Laboratuvar yöntemi daha uygundur & 8 \\
\hline & & $\checkmark$ & Gözlem daha etkilidir & 2 \\
\hline & $\begin{array}{l}\text { Konuya Göre } \\
\text { değişir }\end{array}$ & $\checkmark$ & Konuya göre değişir & 6 \\
\hline \multirow{10}{*}{ 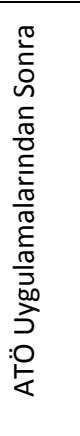 } & \multirow{7}{*}{ Uygun } & $\checkmark$ & Deney öncesi tahminler deney sonrası ge- & 1 \\
\hline & & & rekçeler tartışılır & 2 \\
\hline & & $\checkmark$ & Deney sonrası fikirler kanıtlanır & 1 \\
\hline & & $\checkmark$ & Derse merak artar & 3 \\
\hline & & $\checkmark$ & Dersi daha eğlenceli hale getirir & 1 \\
\hline & & $\checkmark$ & Ortaya atılan iddia deney ile kanıtlanır & 7 \\
\hline & & $\checkmark$ & Etkin ders işlenir & \\
\hline & \multirow[t]{2}{*}{ Uygun Değil } & $\checkmark$ & Kavram haritaları daha uygundur & 1 \\
\hline & & $\checkmark$ & Geleneksel yöntemler daha uygundur & 6 \\
\hline & $\begin{array}{l}\text { Konuya Göre } \\
\text { Değişir }\end{array}$ & $\checkmark$ & Konu iyi seçilirse etkili olur & 6 \\
\hline
\end{tabular}

Tablo 3'e göre, ATÖ yönteminin fen bilimleri laboratuvarında kullanımına ilişkin sınıf öğretmen adaylarının görüşleri doğrultusunda uygulamanın ilk ve son haftalarında uygun, uygun değil ve konuya göre değişir olmak üzere üç alt temanın ortaya çıktığı görülmektedir. Uygulamanın ilk haftasında öğretmen adayları ATÖ yönteminin öğrencilerin ilgisini çekeceği $(f=1)$, etkin ders işlemeyi sağlayacağı $(f=4)$, kalıcı öğrenme sağlayacağı $(f=3)$, bilimsel tartışma becerisi kazandıracağı $(f=1)$ ve yaparak yaşayarak öğrenme ortamı oluşturacağı $(f=1)$ için fen bilimleri laboratuvarında kullanılabilecek uygun bir yöntem olabileceğini belirtmişlerdir. Uygulamanın son haftasında deney öncesi tahminlerin tartışılması deney sonrasında ise gerekçelerin tartışılması $(f=1)$, derse merak artırması $(f=1)$, deney öncesi ortaya atılan iddianın deney sonucunda kanıtlanması $(f=1)$, deney sonrası fikirlerin kanıtlanması ( $f=2)$, dersi daha eğlenceli hale getirmesi $(f=3)$ ve etkin ders işlenmesi $(f=7)$ konularında faydalı olduğu için fen bilimleri laboratuvarında kullanılabilen uygun bir yöntem olduğunu belirtmişlerdir. Uygulamanın ilk haftasında fen bilimleri laboratuvarında gözlem ( $f=2$ ) ve deney yöntemi $(f=8)$ yöntemlerin daha uygun olduğu belirtilirken ATÖ yönteminin ilköğretim öğrencileri için uygun olmadığı ve üst düzey bilgi gerektirdiği için fen bilimleri laboratuvarında kullanımının uygun olmadığı belirtilmiştir. Uygulamanın son haftasında öğretmen adaylarından bir kısmı kavram haritaları $(f=1)$ ve geleneksel labora- 


\section{Gamze KARAER | Ersin KARADEMiR | Özden TEZEL}

tuvar yönteminin $(f=6)$ fen laboratuvarında daha uygun olduğunu belirtmiştir. Ek olarak uygulamanın ilk haftasında ( $f=6$ ) ve son haftasında ( $f=6$ ) bazı öğretmen adayları ATÖ yönteminin fen laboratuvarında kullanılmasının konuya göre değişeceğini belirtmişlerdir. Uygulamanın ilk ve son haftalarında ATÖ yönteminin fen laboratuvarında kullanımının konuya göre değişeceğini belirten öğretmen adayı görüşü sayısı eşitlik göstermektedir. Uygulamanın ilk haftasında bazı öğretmen adayları $(f=2)$ bu konu ile ilgili olarak görüş bildirmezken uygulamanın son haftasında bütün öğretmen adayları bu konu hakkında görüş bildirmiştir. Sınıf öğretmen adaylarının uygulamanın ilk ve son haftalarında ATÖYG formuna verdikleri yanıtların sayısal verileri Şekil 3’te gösterilmektedir.

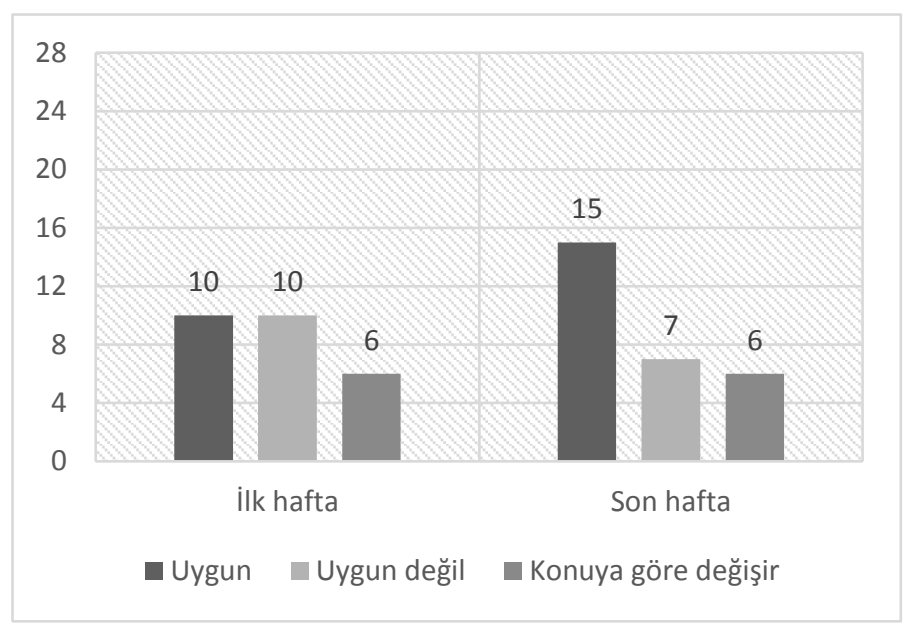

Şekil 3. Sınıf öğretmen adaylarının uygulama öncesi ve sonrası verdikleri yanıtların sayısal değişimi

\subsection{Sınıf Öğretmen Adaylarının ATÖ Yöntemine Yönelik Hazırbulunuşluk Durumları}

Fen bilimleri laboratuvarında uygulamanın ilk ve son haftalarında sınıf öğretmen adaylarına "Argümantasyon Tabanlı Öğretime Giriş Etkinliği (ATÖGE)" formu uygulanmıştır. Bu form ile öğretmen adaylarının ATÖ yöntemine yönelik hazırbulunuşluk durumları belirlenmeye çalışılmıştır. Giriş etkinliği formunun uygulamanın ilk ve son haftasında olmak üzere iki defa uygulanmasındaki amaç, araştırmanın ilk haftasından son haftasına kadar olan süreçte öğretmen adaylarının ATÖ yöntemine yönelik hazırbulunuşluk durumlarında meydana gelen değişimi belirlemektir. Elde edilen veriler doğrultusunda, öğretmen adaylarının ATÖ yöntemine yönelik hazırbulunuşluk durumları formda yer alan soru- 
lara verdikleri cevaplara göre belirlenmiştir. Uygulamanın ilk ve son haftaları arasında belirlenen farklılaşma Şekil 4'de gösterilmektedir.

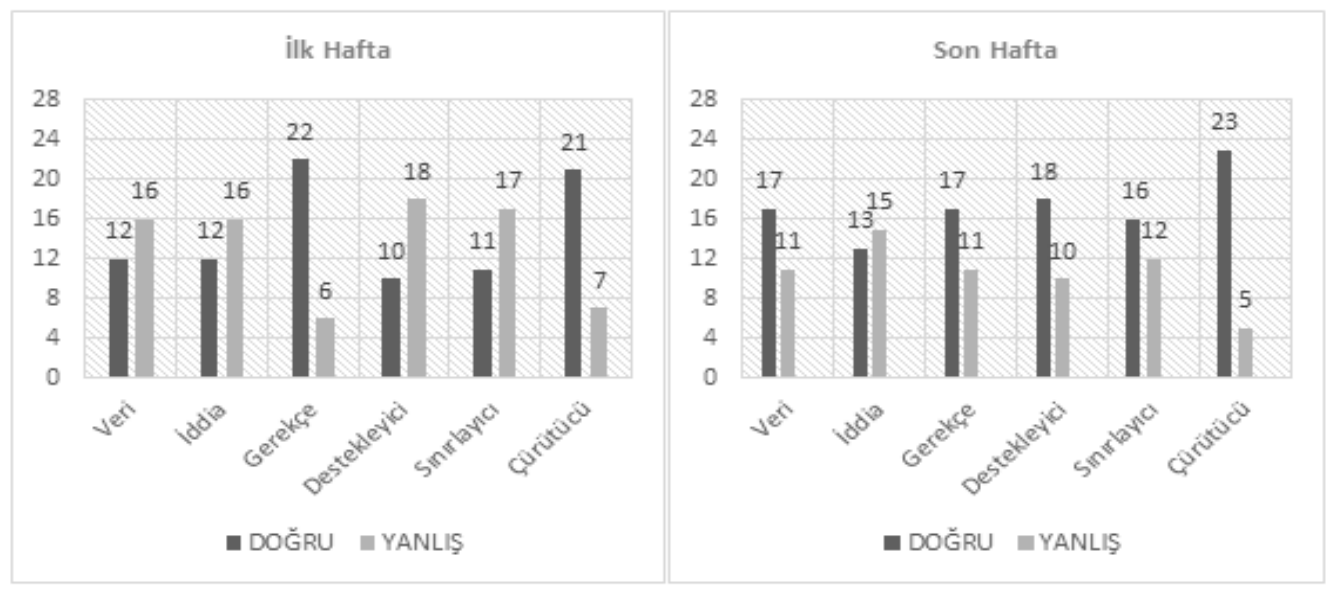

Şekil 4. Uygulamanın ilk haftası ve son haftası arasında meydana gelen farklılaşma

Uygulamanın ilk haftasında öğretmen adaylarına verilen ATÖGE formunda yer alan içi boş argümantasyon modeline yerleştirdikleri cevaplara göre; veri ifadesini 12 öğretmen adayı doğru olarak bulurken 16 öğretmen adayı yanlış olarak bulmuştur. Uygulamanın son haftasında veri ifadesini doğru olarak bulan öğretmen adayı sayısı 17'ye yükselirken yanlış bulanların sayısı 11'e inmiştir. Benzer şekilde içi boş argümantasyon modeline iddia, destekleyici, sınırlayıcı ve çürütücü ifadelerini doğru olarak yerleştiren öğretmen adaylarının sayısı uygulamanın son haftasında artış göstermektedir. Ancak gerekçe ifadesini uygulamanın ilk haftasında doğru olarak bulup modele yerleştiren öğretmen adayı sayısı uygulamanın son haftasında doğru bulan öğretmen adayı sayısından daha fazladır. Şekil 5'e göre, ATÖ giriş etkinliğinin argümantasyon sürecinde kullanılan veri, iddia, gerekçe, sınırlayıcı, destekleyici ve çürütücü gibi ögelerin doğru veya yanlış kullanımına ilişkin öğretmen adaylarının uygulamanın ilk ve son haftalarında sayılarındaki değişim verilmiştir. Uygulamanın ilk haftasında elde edilen bulgular doğrultusunda öğretmen adaylarının en çok destekleyici ve sınırlayıcı kullanmakta sıkıntı yaşadıkları görülürken, en çok gerekçe ve çürütücüleri kullanarak argümantasyon oluşturdukları görülmüştür. Uygulamanın son haftasında öğretmen adaylarının en çok çürütücü ve destekleyici kullandıkları görülürken, en çok iddia kullanma konusunda zorlandıkları görülmüştür. Uygulamanın ilk ve son haftalarında elde edilen bulgulardaki sayısal değişimler incelendiğince, uygulamanın ilk haftasında 22 öğretmen adayı etkinlikte yer alan gerekçeleri doğru olarak kullanırken, uygulamanın son haftasında bu sayı 17'ye düşmüştür. Uygulamanın ilk ve son haftalarında meydana gelen sayısal değişimlere göre "gerekçe" haricinde etkinlikte yer alan 
diğer bütün argümantasyon ögelerini kullanabilen öğretmen adayı sayısında artış gözlenmiştir. Uygulamanın ilk ve son haftalarında meydana gelen sayısal değişimlere göre, en az artışın "iddia” kullanan öğretmen adayı sayısında olduğu görülmüştür. Bulgulara göre, uygulamanın ilk haftasında 12 öğretmen adayı etkinlikte yer alan iddiaları doğru olarak belirlerken, uygulamanın son haftasında bu sayı 13'e yükselmiştir.

\section{Tartışma ve Sonuç}

ATÖ yönteminin kullanıldığı fen bilimleri laboratuvar uygulamalarında sınıf öğretmen adaylarının ATÖ yöntemine yönelik görüşleri ve hazırbulunuşluklarının belirlendiği bu çalışma sonucunda uygulamanın ilk haftasında öğretmen adaylarının ATÖ yöntemine yönelik görüşlerine göre; ATÖ yöntemi olarak tanımlanmış, öğrenci merkezli bir yöntem olduğu için avantajlı, deneylere ağırlık verilemeyeceği ve çekingen öğrenciler için dezavantajlı bir yöntem olduğu belirtilmiştir. Ayrıca, 10 öğretmen adayı argümantasyonun fen bilimleri laboratuvarında kullanılabilcek uygun bir yöntem olabileceğini belirtirken, 10 öğretmen adayı bu yöntemin fen bilimleri laboratuvarında kullanılabilecek uygun bir yöntem olmadığını ve geleneksel laboratuvar yönteminin daha uygun olabileceğini belirtmişlerdir. Ek olarak 6 öğretmen adayı ATÖ yönteminin fen laboratuvarında kullanımının konuya göre değişeceğini belirtmiştir. Uygulamanın son haftasında öğretmen adaylarının görüşleri doğrultusunda ATÖ yöntemini bilimsel tartışma olarak tanımlamışlardır. Öğretmen adayları ATÖ yöntemini bir veriye göre iddia sunmayı, bilgi alış verişi yapmayı, bilgileri tartışarak kalıcı hale getirmeyi, bir iddiaya gerekçeler sunmayı, kanıtlar kullanmayı, bilimsel iddaları deneysel kanıtlarla desteklenmeyi, sınırlayıcılar ve çürütücüler kullanmayı gerektiren faydalı bir yöntem olarak tanımlamışlardır. Uygulamanın son haftasında öğretmen adayları ATÖ yönteminin faydalı bir yöntem olduğunu, bilgileri daha kalıcı hale getirdiğini ve birçok alanda kullanılabileceğini belirtmişlerdir. Bu çalışmanın bulgularına paralel olarak Yıldırır ve Nakiboğlu (2014) çalışmasında kimya öğretmen adaylarının argümantasyona dayalı kimya derslerinin, öğrencilerin bilimsel bilgiyi sorgulama ve bilimsel tartışmayı öğrenerek kendilerine güvenmelerini sağlaması nedeniyle faydalı bir yöntem olduğunu belirtmişlerdir. Benzer şekilde Tümay ve Köseoğlu'na (2011) göre, öğretmen adaylarının görüşleri doğrultusunda argümantasyon odaklı öğretim ile öğrencilerin derse aktif katılımının sağlanacağı, anlamlı öğrenmeler oluşturacakları, düşünme ve sorgulama becerilerinin geliştirileceği belirtilmektedir. Uygulamanın son haftasında öğretmen adaylarının birçoğu görüş olarak ATÖ yöntemini faydalı bir yöntem olarak belirtirken öğretmen adayı yöntemin genellikle zaman kaybına neden olduğunu düşündüklerinden dezavantajlı bir yöntem olduğunu belirtmişlerdir. Argümantasyon yönteminin sınırlılıklarının belirlendiği diğer çalışmalar incelendiğinde, ortaöğretim programını yetiştirme, öğrencilerin bilgi yetersizlikleri, sınıfların kalabalık olması, çekingen öğrencileri olumsuz etkilemesi ve zaman sıkıntısı gibi nedenlerden dolayı bu tür bir yöntemin derslerde kullanımının zor oldu- 
ğunu vurgulamışlardır (Aktamış \& Atmaca, 2016; Yıldırır ve Nakiboğlu, 2014). Bu çalışmadaki bulgulara ek olarak, 15 sınıf öğretmen adayı argümantasyonun fen laboratuvarında kullanılabilcek uygun bir yöntem olabileceğini belirtirken, yedi tane sını öğretmen adayı bu yöntemi fen laboratuvarında kullanılabilecek uygun bir yöntem olmadığını, altı tane sınıf öğretmen adayı ise argümantasyon tabanlı öğretim yönteminin fen laboratuvarında kullanımının konuya göre değişeceğini belirtmişlerdir. Literatürde argümantasyon yönteminin etkililiğinin araştırıldığı nitel çalışmalar incelendiğinde, argümantasyon yönteminin geleneksel yaklaşıma göre daha etkili olduğu, kavramsal öğrenmeyi desteklediği ve öğrenciler tarafından daha çok tercih edildiği görülmektedir (Kabataş Memiş, 2014; Kıngır, Geban, \& Günel, 2011). Uygulamanın ilk haftasında öğretmen adaylarının hazırbulunuşluklarının düşük olduğu ancak argümantasyona dayalı uygulamalardan sonra derse katılımlarında ve argüman öğelerini kullanmalarında artış gözlenmiştir. Uygulamanın ilk haftasında toplamda dört tane öğretmen adayı argümantasyona giriş etkinliğinde yer alan argümantasyon ögelerini tamamen doğru bir şekilde kullanırken, uygulamanın son haftasında bu sayı sekize yükselmiştir. Uygulamanın ilk haftasında etkinlikte yer alan sınırlayıcı ve destekleyici- gibi argüman öğelerini kullanmakta sıkıntı yaşanırken, uygulamanın son haftasında -iddia- kullanımında sıkıntı yaşandığı görülmüştür. Ek olarak uygulamanın ilk haftasında öğretmen adayları en rahat -gerekçe- kullanırken, uygulamanın son haftasında -gerekçe- kullanımında azalma meydana geldiği görülmüştür. Öğreten ve Uluçınar Sağır’a (2014) göre, öğrencilerin en rahat iddia, gerekçe ve destek kullandıkları ancak çürütme ifadelerini kullanamadıkları belirtilmiştir. Bu çalışmada elde edilen bulgular doğrultusunda şu öneriler sunulmuştur;

- Literatürde argümantasyon yöntemi ile ilgili çalışmalar incelendiğinde bu çalışmaların genellikle fen bilgisi öğretmenlerine, fen bilgisi, fizik, kimya, biyoloji öğretmen adaylarına ve ilkokul öğrencilerine uygulandığı görülmektedir. Bu yüzden sınıf öğretmen adayları ile ATÖ yönteminin kullanıldığı daha fazla uygulamaya dönük çalışmalar yapılmalıdır.

- Fen laboratuvar uygulamalarında sınıf öğretmen adaylarının argümantasyon becerilerini geliştirmek için ATÖ yöntemi daha sık kullanılabilir.

- $\quad$ Fen laboratuvar uygulamaları ATÖ yöntemi gibi daha farklı alternatif metotlarla zenginleştirilerek sınıf öğretmen adayları üzerindeki etkileri araştırılabilir. Bu metotlara örnek olarak proje tabanlı öğretim verilebilir.

- Sınıf öğretmen adayları uygulamanın ilk ve son haftalarında yapılan görüşmelerde ATÖ yöntemimin zaman alıc bir yöntem olduğunu bu yüzden fen laboratuvar uygulamalarında deneylere yeteri kadar önem verilemediğini belirtmişlerdir. Bu 
doğrultuda ATÖ yöntemi kullanılarak gerçekleştirilecek uygulamalarda daha basit deneyler seçilebilir.

\section{Kaynaklar}

Akpınar, Y., Ardaç, D., \& Er-Amuce, N. (2014). Development and validation of an argumentation based multimedia science learning environment: Preliminary findings. Procedia - Social and Behavioral Sciences, 116, 3848 - 3853.

Aktamış, H., \& Hiğde, E. (2015). Fen Eğitiminde kullanılan argümantasyon modellerinin değerlendirilmesi. Mehmet Akif Ersoy Üniversitesi Eğitim Fakültesi Dergisi, 35, 136 172.

Aktamış, H. \& Atmaca, A. C. (2016). Fen bilgisi öğretmen adaylarının argümantasyon tabanlı öğrenme yaklaşımına yönelik görüşleri. Elektronik Sosyal Bilimler Dergisi, 15(58), 936-947.

Balcı, C., \& Yenice, N. (2016). Effects of the scientific argumentation based learning process on teaching the unit of cell division and inheritance to eighth grade students. Journal Education in Science, Environment and Health, 2(1), 67-84.

Berland, L. K., \& Mcneil, K. L. (2010). A learning progression for scientific argumentation: Understanding student work and designing supportive instructional contexts. Science Education, 94, 765-793.

Driver, R., Newton, \& P., \& Osborne, J. (2000). Establishing the norms of scientific argumentation in classrooms. John Wiley \& Sons, 84, 287-312.

Erduran, S., Simon, S., \& Osborne, J. (2004). TAPping into argumentation: Developments in the application of Toulmin's argument pattern for studying science discourse. Science Education, 88(6), 915-933.

Erduran, S., \& Jiménez-Aleixandre, M. P. (2008). Argumentation in science education. Perspectives from classroom-Based Research. Dordrecht: Springer.

Giere, R.N. (1991). Understanding scientific reasoning. Forth Worth, TX: Holt, Rinehart \& Winston. 
Günel, M., Kıngır, S., \& Geban, Ö. (2012). Argümantasyon tabanlı bilim öğrenme (ATBÖ) yaklaşımının kullanıldığı sınıflarda argümantasyon ve soru yapılarının incelenmesi. Education and Science, 37(164), 317-328.

Gürdal, A., Şahin, F., \& Çağlar, A. (2001). Fen eğitimi ilkeler, stratejiler ve yöntemler. İstanbul: Marmara Üniversitesi.

Gürdoğan-Bayır, Ö., Göz, N. L., \& Bozkurt, M. (2014). Sınıf öğretmeni adaylarına göre sosyal bilgiler dersinde küresel vatandaşlık. Eğitim Bilimleri Araştırmaları Dergisi, 4(2), 145-162.

Hiğde, E., \& Aktamış, H. (2017). Fen bilgisi öğretmen adaylarının argümantasyon temelli fen derslerinin incelenmesi: Durum çalışması. Illköğretim Online, 16(1), 89-113.

Kabataş Memiş, E. (2014). Illköğretim öğrencilerinin argümantasyon tabanlı bilim öğrenme yaklaşımı uygulamalarına ilişkin görüşleri. Kastamonu Eğitim Dergisi, 22(2), 401-418.

Karaer, G. (2016). Fen laboratuvarında sınıf öğretmeni adaylarına uygulanan argümantasyon ve proje tabanlı öğretim yöntemlerinin etkililiğinin incelenmesi (Yayınlanmamış yüksek lisans tezi). Eskişehir Osmangazi Üniversitesi, Eskişehir.

Kaptan, F., \& Aydın, Ö. (2014). Fen-teknoloji öğretmen adaylarının eğitiminde argümantasyonun biliş üstü ve mantıksal düşünme becerilerine etkisi ve argümantasyona ilişsin görüşler. Eğitim Bilimleri Araştırmaları Dergisi, 4(2), 164-188.

Kelly, G. J., \& Takao, A. (2002). Epistemic levels in argument: An analysis of university oceanography students' use of evidence in writing. Science Education, 86(3), 314342.

Kıngır, S., Geban, Ö., \& Günel, M. (2011). Öğrencilerin kimya derslerinde argümantasyon tabanlı bilim öğrenme yaklaşımının uygulanmasına ilişkin görüşleri. Selçuk Üniversitesi Ahmet Keleşoğlu Eğitim Fakültesi Dergisi, 32, 15-28.

Koçak, K. (2013). Argümantasyon tabanlı bilim öğrenme yaklaşımının öğretmen adaylarının çözeltiler konusunda başarısına ve eleştirel düşünme eğilimlerine etkisi (Yayımlanmamış yüksek lisans tezi), Hacettepe Üniversitesi, Ankara. 


\section{Gamze KARAER | Ersin KARADEMiR | Özden TEZEL}

Lawson, A. (2003). The nature and development of hypothetico-predictive argumentation with implications for science teaching. International Journal of Science Education, 25(11), 1387-1408.

McNeil, K. L. (2011). Elementary students' views of explanation, argumentation, and evidence, and their abilities to construct arguments. Journal of Research in Science Teaching, 48, 793-823.

McNeill, K. L., \& Krajcik, J. S. (2012). Supporting grade 5-8 students in constructing explanations in science: The claim, evidence, and reasoning framework for talk and writing. Boston: Pearson.

MEB. (2006). Ilköğretim Fen ve Teknoloji Dersi (6, 7 ve 8. Sınıflar) Öğretim Programı. Ankara: Milli Eğitim Bakanlığı.

MEB. (2013). Ilköğretim Kurumları (ilkokullar ve Ortaokullar) Fen Bilimleri Dersi (3, 4, 5, 6, 7 ve 8. sınıflar) Öğretim Programı. Ankara: Milli Eğitim Bakanlığı.

MEB. (2017). Fen Bilimleri Dersi Öğretim Programı (ilkokul ve Ortaokul 3, 4, 5, 6, 7 ve 8. Sınıflar). Ankara: Milli Eğitim Bakanlığı.

MEB. (2018). Fen Bilimleri Dersi Öğretim Programı (ilkokul ve Ortaokul 3, 4, 5, 6, 7 ve 8. Sınıflar). Ankara: Milli Eğitim Bakanlığı.

Osborne, J., Erduran, S., \& Simon, S. (2004). Enhancing the quality of argumentation in school science. Journal of Research in Science Teaching, 41(10), 994-1020.

Öğreten, B. \& Uluçınar Sağır, Ş. (2014). Argümantasyona dayalı fen öğretiminin etkililiğinin incelenmesi. Türk Fen Eğitimi Dergisi, 11(1), 76-100.

Sandoval, W. A. (2003). Conceptual and epistemic aspects of students' scientific explanations. The Journal of the Learning Sciences, 12(1), 5-51.

Schwarz, B. B., Neuman, Y., Gil, J., \& Ilya, M. (2003). Construction of collective and individual knowledge in argumentative activity. The Journal of the Learning Sciences, 12(2), 219-256. 
Simon, S., Erduran, S., \& Osborne, J. (2006). Learning to teach argumentation: Research and development in the science classroom. International Journal of Science Education, 28(2-3), 235-260.

Suzuki, K. Yamaguchi, E., \& Hokayem, H. (2015). Learning progression for Japanese elementary students' reasoning about ecosystems. Procedia - Social and Behavioral Sciences, 167(2015), $79-84$.

Şahin, F., \& Hacıoğlu, Y. (2010). Bilimsel tartışma destekli örnek olayların 8. sınıf öğrencilerinin "kalıtım" konusunda kavram öğrenmelerine ve okuduğunu anlama becerilerine etkisi. International Conference on New Trends in Education and Their Implications, 269-274.

Toulmin, S. E. (2003). The uses of argument. Cambridge: Cambridge University Press.

Tümay, H., Köseoğlu, F., \& Budak, E. (2008). Bilimin doğası hakkında paradigma değişimleri ve öğretimi ile ilgili yeni anlayışlar. Gazi Eğitim Fakültesi Dergisi, 28(2), 221.

Tümay, H., \& Köseoğlu, F. (2011). Kimya öğretmen adaylarının argümantasyon odaklı öğretim konusunda anlayışlarının geliştirilmesi. Türk Fen Eğitimi Dergisi , 8(3), 105119.

Üstünkaya, I. \& Savran Gencer, A. (2012). Ilköğretim 6. Sınıf Seviyesinde Bilimsel Tartışma (Argumentation) Odaklı Etkinliklerle Dolaşım Sistemi Konusunun Öğretiminin Akademik Başarıya Etkisi. X. Ulusal Fen ve Matematik Eğitimi Kongresi.

Yan, X. \& Erduran, S. (2008). Arguing online: Case studies of pre-service science teachers' perceptions of online tools in supporting the learning of arguments. Turkish Science Education, 5(3), 2-31.

Yeşildağ Hasançebi, F., \& Günel, M. (2013). Effects of argumentation based inquiry approach on disadvantaged students' science achivement. Elementary Education Online, 12(4), 1056-1073.

Yıldırım, A., \& Şimşek, H. (2015). Döküman incelenmesi sosyal bilimlerde nitel araştırma yöntemleri. Ankara: Anı Yayıncılık. 
Yıldırır, H. E. \& Nakiboğlu, C. (2014). Kimya öğretmen ve öğretmen adaylarının derslerinde kullandıkları argümantasyon süreçlerinin incelenmesi. Abant izzet Baysal Üniversitesi Eğitim Fakültesi Dergisi, 14 (2), 124-154.

Zohar, A., \& Nemet, F. (2002). Fostering students' knowledge and argumentation skills through dilemmas in human genetics. Journal of Research in Science Teaching, 39(1), 35-62.

\section{Ek-1: Argümantasyon Tabanlı Öğretime Yönelik Görüş (ATÖYG) Formu Soruları}

1) Argümantasyon deyince aklınıza neler geliyor?

2) Fen bilimleri laboratuvar uygulamalarında yapılan deneylerin/etkinliklerin ATÖ yöntemi kullanılarak yürütülmesi nasıl olur? Neler düşünüyorsunuz?

3) Sizce fen bilimleri laboratuvar uygulamalarında ATÖ yöntemi kullanılarak gerçekleştirilen deneylerin/etkinliklerin geleneksel laboratuvar uygulamalarından ne gibi farklılıkları olabilir?

4) Fen bilimleri laboratuvar uygulamalarında yapılan deneylerin/etkinliklerin ATÖ yöntemi ile yürütülmesinin güçlü ve zayıf yanları neler olabilir?

5) Sizce ATÖ yöntemi ile fen bilimleri laboratuvar uygulamaları dersi nasıl daha etkili bir şekilde planlanabilir? Önerileriniz nelerdir? 


\section{Ek-2: Argümantasyon Tabanlı Öğretime Giriş Etkinliği (ATÖGE) Formu}

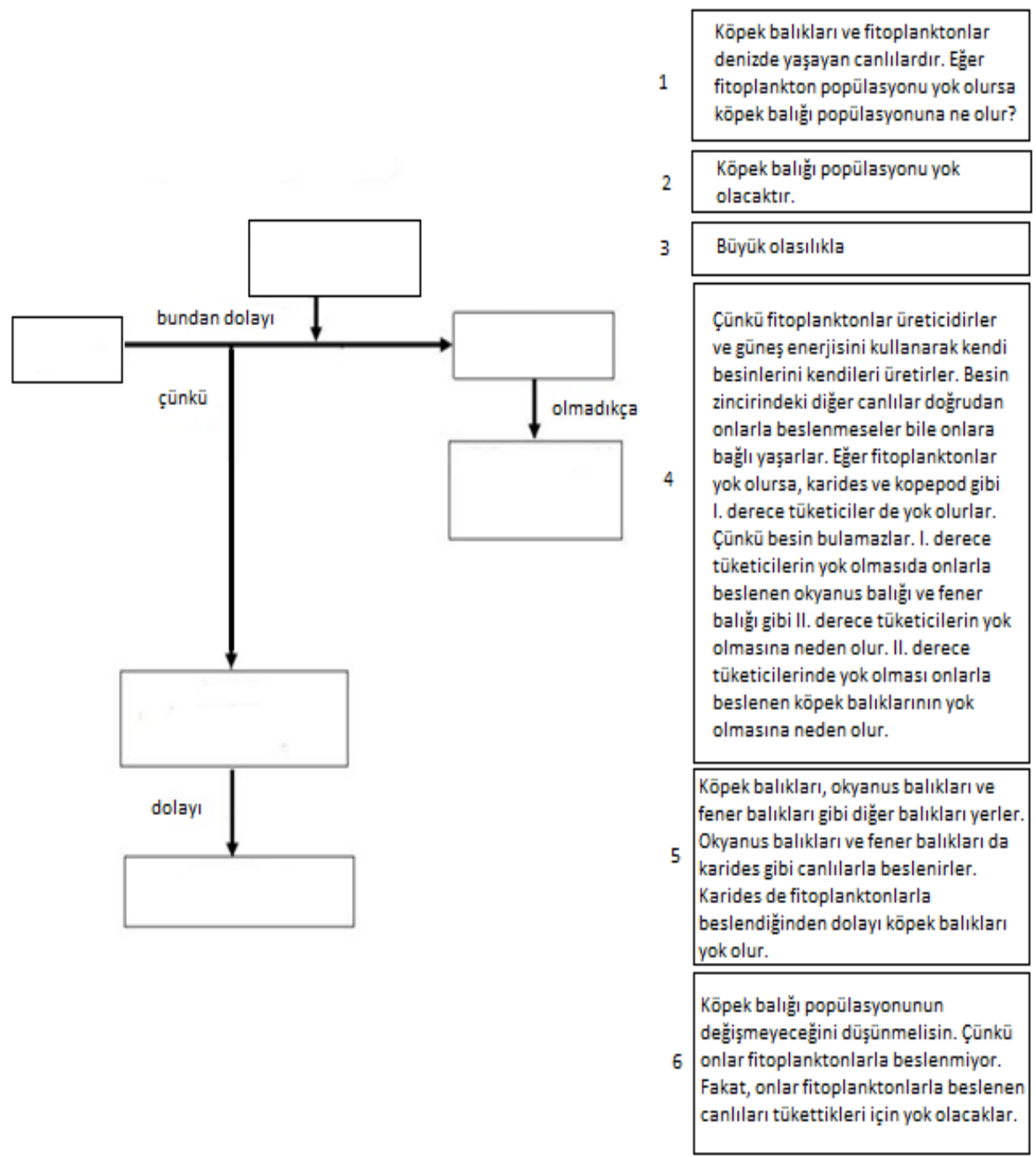

